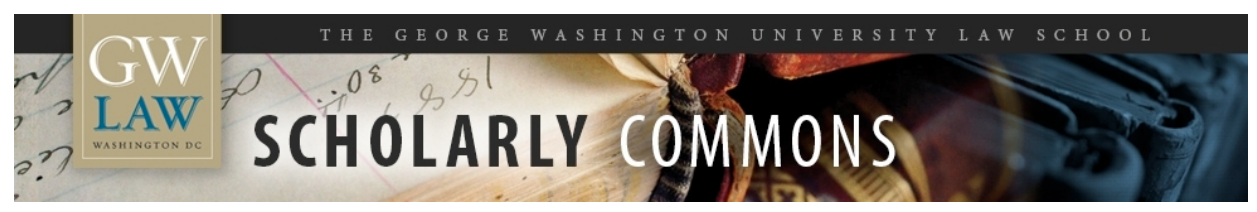

\title{
Reinvigorating Innovation: Lessons Learned from the Wright Brothers
}

\author{
Steven L. Schooner \\ George Washington University Law School, sschooner@law.gwu.edu
}

Nathaniel E. Castellano

Follow this and additional works at: https://scholarship.law.gwu.edu/faculty_publications

Part of the Law Commons

\section{Recommended Citation}

Schooner, Steven L. and Castellano, Nathaniel E., Reinvigorating Innovation: Lessons Learned from the Wright Brothers (April 2016). Contract Management, Volume 56, Page 46 (April 2016); GWU Law School Public Law Research Paper No. 2016-8; GWU Legal Studies Research Paper No. 2016-8. Available at SSRN: http://ssrn.com/abstract=http://ssrn.com/abstract=2758727

This Article is brought to you for free and open access by the Faculty Scholarship at Scholarly Commons. It has been accepted for inclusion in GW Law Faculty Publications \& Other Works by an authorized administrator of Scholarly Commons. For more information, please contact spagel@law.gwu.edu. 

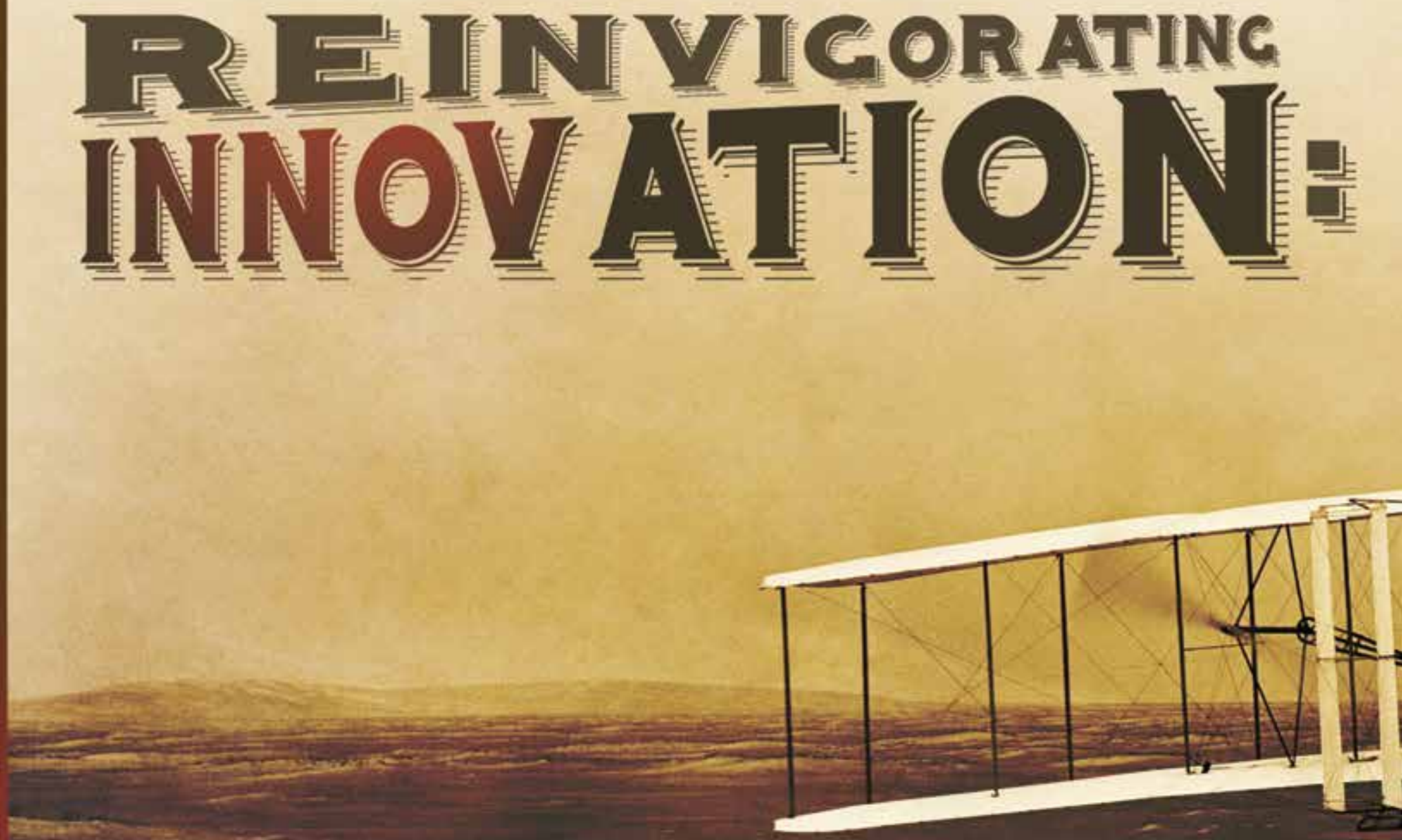


\section{bessons bearned from the WRIGHT BROTHERS}

BY STEVEN L. SCHOONER \& NATHANIEL E. CASTELLANO
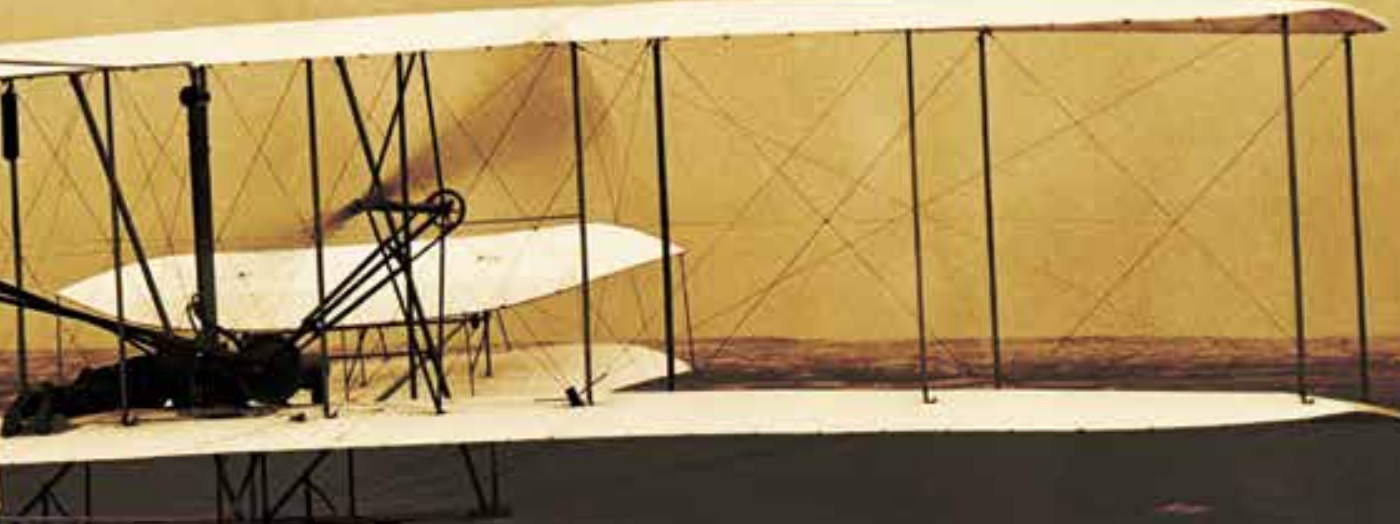

Innovation does not evolve in a vacuum;

and, in order to maintain technological

superiority, DOD should review a few

lessons it learned from the Wright brothers

in order to foster and incentivize collaborative

R\&D in the present and the future. 


\section{Eam] concern[ed] that...[DOD]
may not be pushing the state-
technical performance. This endangers
-Frank Kendall, Under Secretary of Defense (Acquisition, Technology, and logistics) ${ }^{1}$}

Military superiority depends, in part, on a never-ending, dogged, and relentless pursuit of technological advancement. In this pursuit, the scientific method practically dictates that failures will outnumber successes.

Undoubtedly, you are familiar with anecdotes of staggering investments in under-performing, government-driven research and development (R\&D) initiatives. Today, a consistent media drumbeat highlights the delays, cost overruns, and performance concerns surrounding the joint strike fighter and other major systems. ${ }^{2}$ On closer examination, these failures often derive from a dysfunctional approach to the process of innovation rather than the natural effects of trial and error. Indeed, the defense acquisition community, saddled with severe post-recession fiscal constraints and a dysfunctional budget system, increasingly appears to adopt risk-averse practices that stifle and undermine innovation. These trends are cause for concern.

The Department of Defense (DOD) recognizes that it must do more to spur innovation. ${ }^{3}$ Recently, Frank Kendall, under secretary of defense (acquisition, technology, and logistics) has honed his warning that DOD is underinvesting in maintaining its technological edge:

Over the past few decades,
the U.S. and our allies
have enjoyed a military
capability advantage over
any potential adversary....
It has been a good run, but
the game isn't one sided,
and all military advantages
based on technology are
temporary.
-Frank Kendall,
Testimony Before the
House Committee on
Armed Services
(January 28, 2015)

The rise of foreign capability, coupled with the overall decline in U.S. research and development investments, is jeopardizing our technological superiority. ${ }^{4}$

In light of DOD's interest in deploying procurement methods with the potential to harness American ingenuity and ensure battlefield superiority, we suggest that DOD's leadership make time for David McCullough's recent biography, The Wright Brothers, ${ }^{5}$ as an aviation anecdote chockfull of fundamental lessons DOD must embrace to succeed.

McCullough is one of the nation's most popular biographer historians for a reason. His book is an entertaining re-introduction to the Wright family and an informative examination of one of the most iconic and significant moments in paradigm-shifting innovation. In that regard, it offers an ideal window into the often-understated human aspects of the R\&D process.

\section{THINK CREATIVELY TO FIND CREATORS}

The Wright Brothers takes us back to a time when human flight, aeronautics, and aviation were synonymous with witchcraft and wizardry. Two young men imagined that they could achieve what conventional wisdom and folklore deemed impossible. This great American epic is a tale of modest, self-made bicycle mechanics, lacking college education, ${ }^{6}$ but emboldened by a penchant for bird-watching, who dared to imagine, design, build, test, fly, master, and market the world's first lighter-than-air flying 


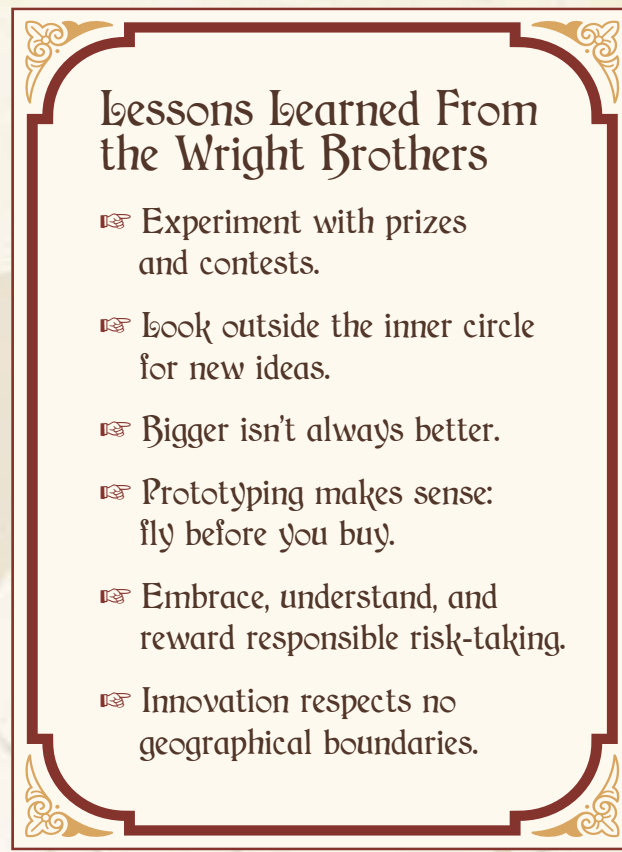

machine-all without government funding. As DOD rethinks its approach to stimulate innovation, surely such an extraordinary story contains valuable insights.

\section{EMBRACE PRIZES AND CONTESTS}

A repeated theme in The Wright Brothers is the influence of European (and later, American) prizes and contests intended to spur innovation and foster competition. These high-profile monetary and nonmonetary rewards served as a potent accelerant to aviation innovation early in twentieth century. Privately funded prize contests such as the 1908 Michelin Prize (won by Wilbur Wright) and the 1927 Ortieg Prize (claimed by Charles Lindbergh in the Spirit of St. Louis) set the stage for modern privately funded contests such as the 2004 Ansari XPrize (resulting in the public debut of thenmaverick SpaceX).

Lucrative prizes, of course, precede human flight. As early as 1567, European sovereigns offered prizes for a solution to the vexing problem of accurately determining a ship's longitude at sea, culminating in the eponymous 1714 Longitude Prize. ${ }^{7}$ Unlike government contracts and grants-i.e., the conventional, heavily regulated, cumbersome, scandal-laden, and oft-criticized

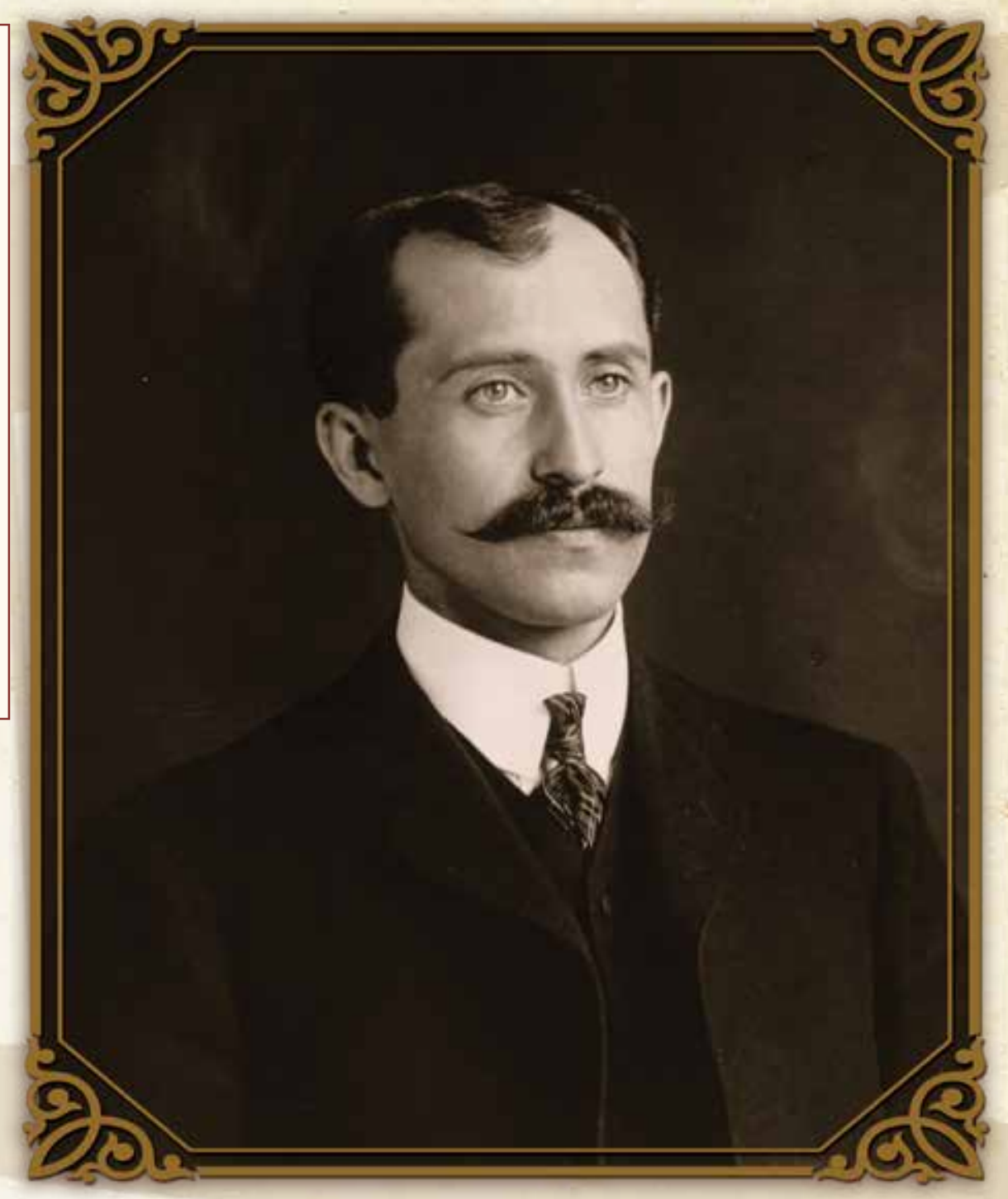

Orville Wright, Age 34

Courtesy of: Library of Congress (LC-DIG-ppmsc-06102)

vehicles they tend to replace-prizes shift $R \& D$ risk to the private sector and provide governments access to previously untapped innovative talent.

Unlike traditional, bilateral R\&D contracts, where the government chooses a single (or very small number of) business partner(s) in anticipation of performance, prizes engage a theoretically infinite number of contestants who are only rewarded if and when one or more contestant satisfies the contest criteria. Deploying an unlimited number of highly motivated, independent research initiatives increases the odds that the government will benefit from novel approaches.
Contests shift the risk of failure (i.e., the risk that effort will be expended without compensation) to contestants. Rather than agreeing to reimburse the private sector for effort expended in advancing the state of the art, the government only pays for success. This, in effect, harnesses the potential of the trial-and-error approach to innovation that served the Wrights so well. The government is not the only benefactor of the prize contest arrangement-innovators rush to invest their resources in contests to claim hefty financial rewards and crave the priceless imprimatur that accompanies success. Winning a high-profile government contest showers publicity of the type that 





a public relations firm might promise, but likely cannot deliver.

Exploiting the renewed popularity and seemingly limitless potential of prizes, President Barack Obama formally encouraged federal agencies to adopt prize contests, and shortly thereafter, Congress authorized federal agencies to conduct prize contests. ${ }^{8}$ Despite the compelling empirical, theoretical, and anecdotal evidence in favor of prizes, they remain relatively novel among federal agencies. This is particularly disappointing in the aerospace arena, as an increasingly consolidated industrial base of airframe manufacturers dominate the industry, which potentially stifles DOD's ability to discover the dramatic ideas that could animate the future of air supremacy.

\section{QUESTION CONVENTIONALITY; BEWARE OVERRELIANCE ON THE INNER CIRCLE}

The success of privately sponsored prize contests in the aviation industry also bolsters the idea that breakthrough solutions are most likely to come from perspectives outside the relevant scientific discipline. In this respect, the Wright brothers, who transitioned from printing newspapers and selling bicycles to unlocking the mystery of flight, are not alone. John Harrison, who solved the centuries-old problem of calculating a ship's longitude at sea, was a self-taught clockmaker, not a navigator. Napoleon's 1795 Food Preservation Prize champion, Nicolas Appert, was a confectioner before he invented the modern practice of canning. More recently, the "Mapping Dark Matter Competition" was claimed by a glaciology PhD student who crafted an algorithm-in less than one week-that out-performed state-of-the-art solutions proposed by leading physicists. ${ }^{9}$

In the last century, many notable advances in aviation navigated and survived the government's highly regulated and burdensome R\&D, production, deployment, and foreign military sale processes. But could it be that the 2012 success of SpaceX's

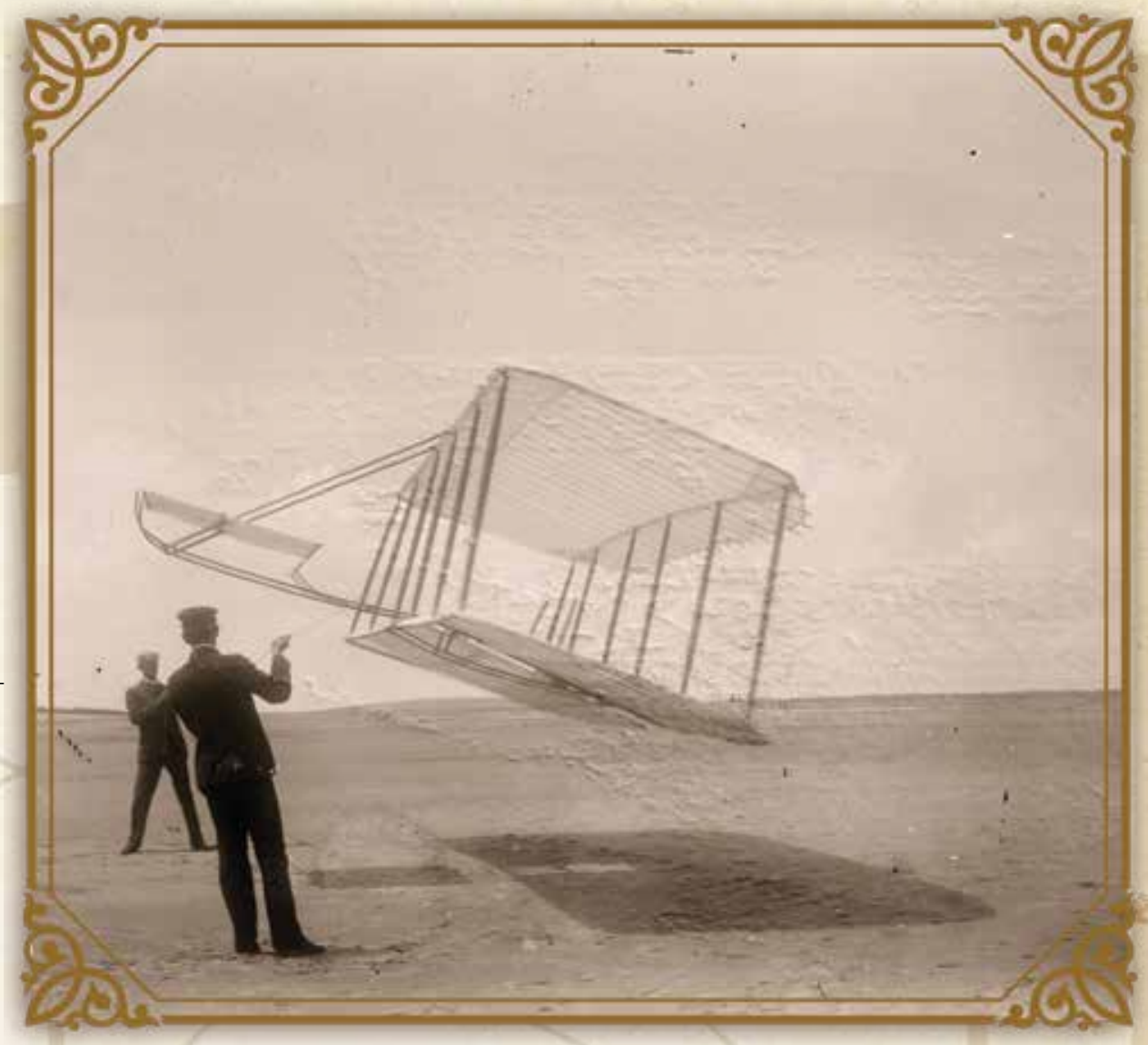

Side view of glider flying as a kite near the ground, Wilbur at left and Orville at right, glider turned forward to right and tipped downward Courtesy of: Library of Congress (LC-DIG-ppmsc-06102)

Dragon-the first nongovernmental commercial spacecraft to deliver cargo to (and return with cargo from) the International Space Station ${ }^{10}$ - was needed to remind us that the Wright brothers were little-known, lightly regarded "outsiders"? Given the dire fiscal environment, increasing consolidation in the U.S. aerospace industry, ${ }^{11}$ and government silos in innovation, DOD must embrace outsiders and jettison the biases it exhibited with regard to outside-of-the-box innovative military solutions in the early 1900s. What better time than today to question conventional wisdom?

\section{BICCER ISN'T ALWAYS BETTER}

McCullough's biography offers bountiful ammunition supporting the theory that off-the-radar small businesses and the individuals behind them may offer the most fruitful sources of innovation-as opposed to the large, sophisticated, established, and potentially bureaucratic corporations that dominate the modern aerospace industry.

McCullough makes much of the U.S. government's unwillingness to take seriously the bicycle-building brothers from Dayton. Even after the Wright brothers successfully demonstrated flight, the U.S. War Department completely ignored them, preferring instead to sink money into "The Great Aerodrome," piloted by the high-profile Samuel Langley and underwritten by the Smithsonian. On July 14, 1903, on the banks of the Potomac River in Quantico-just days before the Wright brothers made their historic flight at the then-remote and secluded Kitty Hawk - Langley's flawed behemoth sank moments after it took off. Given the government funding and resources that sank with it, the contrast between the brothers' success and the government's failure could not be more stark: 
[N]either [Orville nor Wilbur] ever said the stunning contrast between their success and Samuel Langley's full-scale failure just days before made what they had done on their own all the more remarkable.... [T]he Langley project had cost nearly $\$ 70,000$, the greater part of it public money, whereas the brothers' total expenses for everything from 1900 to 1903, including materials and travel to and from Kitty Hawk, came to a little less than $\$ 1,000$, a sum paid entirely from the modest profits of their bicycle business. ${ }^{12}$

Governments tend toward this kind of behavior. In his compelling history of the Predator drone, Richard Whittle chronicled the quest of Abraham (Abe) Karem, a Baghdad-born Israeli engineer whose inability to thrive within the bureaucracies of the Israeli Air Force and Israel aerospace industries led to his emigration to the United States. ${ }^{13}$ Like the Wright brothers, whose creative genius flourished in the family bicycle store and on windswept beaches, Karem's vision for remotely-controlled flight was conceived outside of the established domestic industrial base.

With so much time and attention focused on the joint strike fighter, next-generation long range strike bomber, and other increasingly dominant, all-encompassing weapons systems, ${ }^{14}$ we fear DOD reverting to the instincts that drew it to the attractive but ultimately ineffective Great Aerodrome. One wonders what revolutionary innovations by modern-day Wright brothers the Pentagon may have ignored. Can the United States avoid missing out on-and instead spur-innovation in its own back yard? While we believe that prize contests may attract new ideas, we also believe that jettisoning fixed-price R\&D contracts - which prioritize arbitrary budgets over proven performanceand investing in competitive prototypes would pay exponential dividends.

\section{THE POWER OF PROTOTYPINC: FLY BEFORE YOU BUY}

A century ago, the government customers featured in The Wright Brothers understood a fundamental, simple, and commonsense acquisition proposition: “Don’t buy it until you fly it." Unfortunately, this basic commercial purchasing principle was lost somewhere during the 20th century transition from the War Department to the leviathan, process-oriented, congressionally micromanaged, and budget-challenged DOD.

Prototyping is neither novel nor revolutionary; indeed, longstanding defense and federal acquisition policy favors such a systematic approach. ${ }^{15}$ Delaying production commitments until after concept demonstration and validation increases the government's up-front R\&D investment in the pursuit of confirming operability and ensuring longterm return on investment. Unfortunately, DOD has eschewed flying prototypes-let alone competitive prototypes-for the KC-X (the in-flight refueling tanker, even though the procurement was billed as a commercial acquisition) and, more recently, the nextgeneration long range strike bomber. ${ }^{16}$

DOD - and Congress, the media, and the public-is increasingly critical of dramatic cost overruns, an entirely predictable outcome when the government commits to unproven technological solutions for which estimating production costs is obviously premature. If the government wants to know-rather than guess-what a major defense program will cost, and, more important, what value that program will provide, it must collect data through operational testing before the R\&D process transitions to full production. Customers lack the critical information necessary to grasp how expensive, reliable, and capable an airframe is until they fly it-and maybe even crash it. Instead of awarding large-scale, generation-spanning production contracts based upon promises made before the development and testing cycle is complete, the government should consider and vigorously test alternative approaches until a proven platform emerges.

A prudent long-term investment approach would pay multiple competitors to develop, field, and test a prototype. End-users and stakeholders-including pilots, missile and munitions teams, mechanics, wing commanders, strategists, and, yes, accountants-could form a better idea of what the actual functionality, customer satisfaction, and programmatic cost might be before the government chose its long-term business partner. Experience confirms that fielding a weapon system - and actually using it-is a very different experience from reading (or dreaming) about it.

A valuable spillover of prototyping is the potential for a more robust and accurate projection of a program's life cycle cost, ${ }^{17}$ rather than exclusive-and naïve-reliance on purchase price. Life cycle cost takes into account the total cost to purchase, field, deploy, arm, maintain, improve, sustain, and ultimately retire a weapon system. In other words, life cycle cost reflects what the government actually pays for the performance it receives.

DOD understands that the cost of building and flying prototypes is fully justified in order to save money (not to mention save lives and ensure battlefield superiority) over the several decades that airframes stay in service. Sadly, DOD currently lacks the stomach to confront-and Congress lacks the sophistication to grasp-the necessity of making short-term investments to achieve long-terms savings. In the modern era of short-sighted, budget-driven decisionmaking, ${ }^{18}$ DOD could be forgiven were the stakes not so high.

\section{RISK: NOT JUST COST OVERRUNS AND DELAYS}

Innovation entails risk, and the Wright

brothers remind us that risk involves matters more significant than cost overruns, schedule slippage, or degradation of aspirational performance specifications. Every time the brothers tested their flying machine, they risked their lives.

Early on, the brothers decided never to fly together. If one brother died, the other could continue their quest. The brothers understood the necessity of risk-taking, and their willingness to assume the ultimate risk set them apart from leading figures in aviation theory-most of whom never attempted flight. 
Flying machines crash, and (test) pilots and their passengers do not always survive. ${ }^{19}$ Orville nearly died in the Fort Myer crash that claimed the life of Army Lieutenant Thomas Selfridge. ${ }^{20}$

In recounting Wilbur Wright's first public speech on flight, later dubbed "The Book of Genesis of the twentieth-century Bible of Aeronautics," McCullough described the Wright Brothers' risk calculus:

What was needed...for success with a flying machine....was the ability to ride with the wind, to balance and steer in the air. [Rather than]...explain how a bird could soar through the air[,]...he took a sheet of paper, and...let it drop. It would not "settle steadily down as a staid, sensible piece of paper ought to do, but it insists on contravening every recognized rule of decorum, turning over and darting hither and thither in the most erratic manner, much after the style of an untrained horse." This was the kind of horse, he said, that men had to learn to manage in order to fly, and there were two ways: "One is to get on him and learn by actual practice how each motion and trick may be best met; the other is to sit on a fence and watch the beast a while, and then retire to the house and at leisure figure out the best way of overcoming his jumps and kicks. The latter system is the safest, but the former, on the whole, turns out the larger proportion of good riders."21

The Wright brothers' courage and example resonates today. Frank Kendall bemoaned that, in a challenging environment dominated by tight budgets and an emphasis on compliance:

[DOD] may not be pushing the stateof-the-art enough in terms of technical performance.... Simply delivering what was initially required on cost and schedule can lead to failure in achieving our evolving national security mission-the reason defense acquisition exists in the first place.... ${ }^{22}$

The potential cost of systemic risk aversionconservative unwillingness to take risks and fail-does not bode well for DOD's ability to sustain technological battlespace superiority.
The Wright brothers willingly assumed great risk in the name of technological progress, but they took that risk on their own terms. The brothers never rushed laborious pre-flight inspections, and wind conditions frequently prompted cancellations. Despite enormous pressure, Orville and Wilbur understood that-to properly mitigate risk-they must sometimes disappoint thousands of spectators, including hundreds of congressman, senators, military officers, and potential customers. ${ }^{23}$

\section{INNOVATION RESPECTS NO CEOCRAPHICAL BOUNDARIES}

America's hubris with regard to its technical superiority and its historical status as a unique incubator for creative, innovative, and entrepreneurial endeavor must be critically reexamined. Innovation, and, more broadly, intellectual capital, respects no geographical boundaries. Any technological advantage the United States may have historically enjoyed is rapidly eroding:

\section{[U.S.] government policies no longer shape industry environment as much as they did in the past.... As long as the nation's pre- dominance in the global advanced technol- ogy sector is under relative erosion, the U.S. will no longer be able [to] dominate entire global value chains.... When U.S.-based companies do dominate critical value ac- tivities, the latter tend to rely on strategic alliances with foreign corporations. ${ }^{24}$}

In other words, innovation cannot be perceived as a domestic sport over which Americans enjoy a natural monopoly. Globalization-and competition from abroad-cannot be ignored.

Even though it played out in a far more insular and dramatically less globalized community, one of the most remarkable aspects of the Wright Brothers' story was their success despite the U.S. government's utter and complete disregard for their endeavors. Instead of investigating and incubating this transformative technology that would forever change the nature of warfare and civilian travel, the

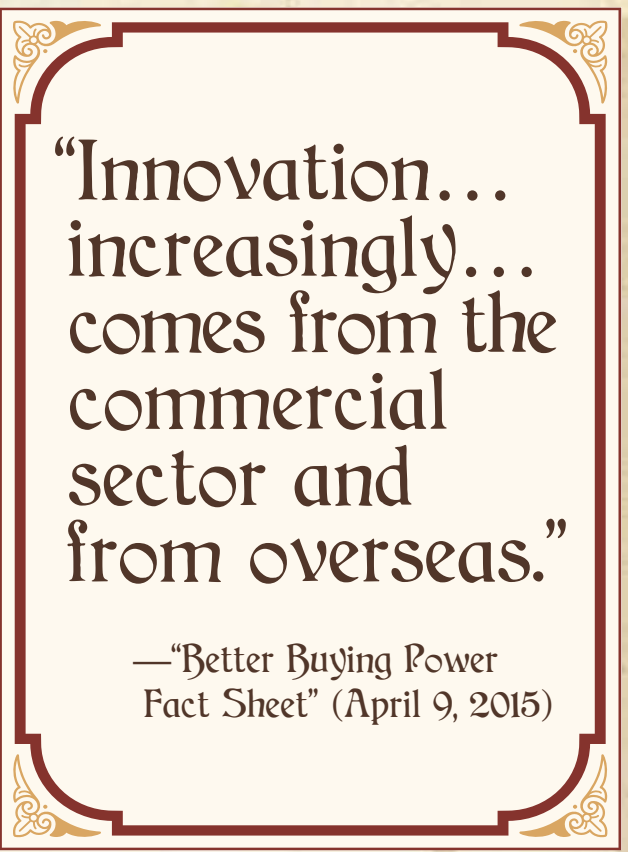

United States rebuffed the Wright Brothers and turned a blind eye until their machineand the skills necessary to harness it-were publicly demonstrated, celebrated, taught, and sold-in Europe.

After their success at Kitty Hawk, the brothers' sense of patriotic duty outweighed any sting of rejection, such that they gave their country one last chance before taking their wares to Europe. ${ }^{25}$ Their persistence proved fruitless. Despite their description of their successful 1904 trial flights, and the fact that the Wrights made no appeal for financial support, the War Department answered with a boilerplate rejection letter. ${ }^{26}$

When Wilber Wright arrived in Europe shortly thereafter, he was warmly welcomed and celebrated. (Fortunately, for the Wrights and the aviation industry, this was a time before export controls may have made such an excursion impossible. ${ }^{27}$ ) Wilbur flew hundreds of public demonstrations in several countries, enthusiastically attended by military and public officials, celebrities, royalty, and throngs of people that traversed Europe chasing rumors that Wilbur Wright would make their wildest dreams come true. The French benefitted the most from this cultural exchange. The French pilots Wilbur Wright trained almost immediately began challenging the Wrights 


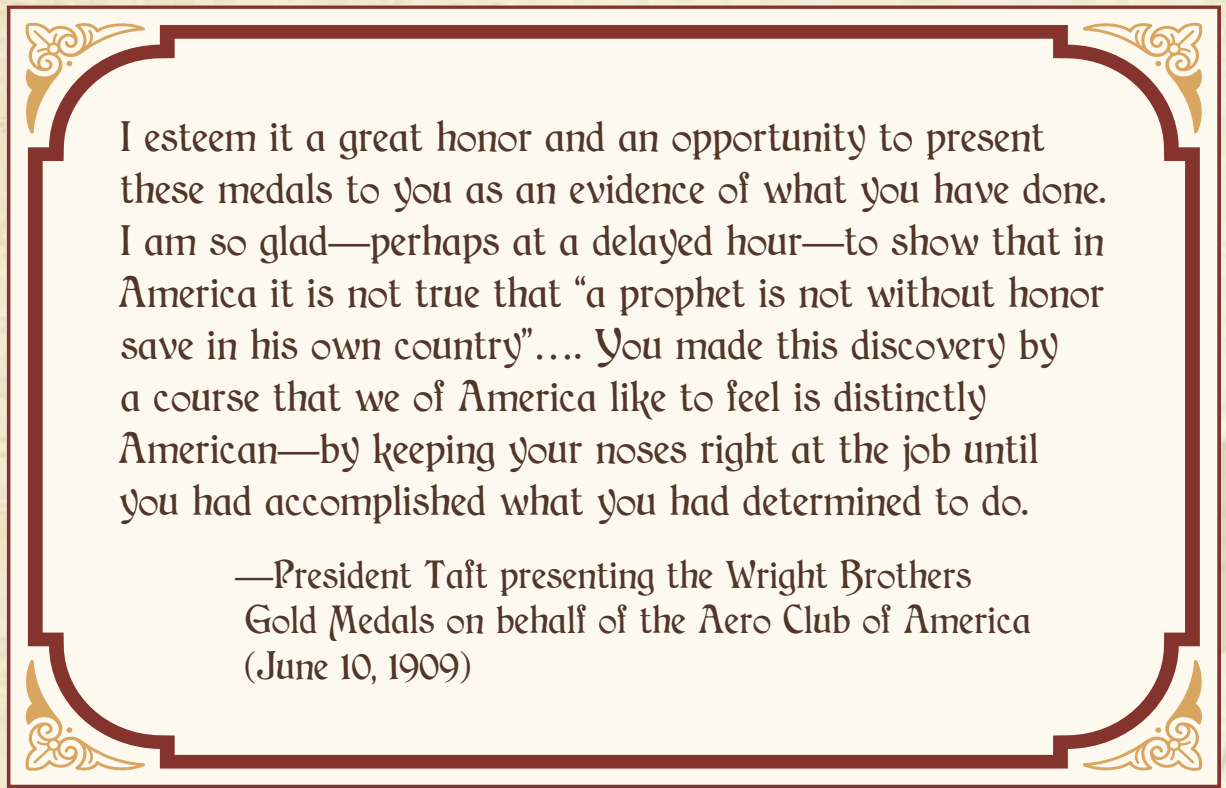

as record-setting aviators using the Wright machines and-leading up to World War Ithe French aviation industry blossomed.

By the time the Wright brothers signed their first contract with the U.S. War Department, worth $\$ 25,000,{ }^{28}$ the brothers had received $\$ 35,000$ from French Syndicate payments, prize money, and cash awards, not including the contract signed with the French government. In total, their exploits in Europe resulted in over $\$ 300,000$ in contracts and prizes.

No U.S. government funding, policy, or initiative contributed to the Wright brothers embarking upon their ambitious quest. Nor did government efforts to nurture a nascent industry propel them past any significant hurdle. Ultimately, the U.S. government consistently failed to invest in, let alone sustain, accelerate, or foster their efforts. Conversely, European enthusiasm-backed by generous private and public funding-empowered the rapid evolution of the burgeoning aviation industry.

In an increasingly globalized technological environment, DOD must reimagine its relationship with its allies in the pursuit of technological superiority. Among other things, DOD needs to build bridges with its allies to foster and incentivize collaborative R\&D.

\section{CONCLUSION: INCENTIVES, IMACINATION, AND INNOVATION}

The McCullough biography points to any number of Wright family traits that led to their success. The brothers were exhaustive researchers and the kind of tireless workers frequently branded-and sometimes derided-as "grinders." But the Wright brothers were also visionaries on the grandest scale, reshaping the art of the possible by painstaking trial and error and meticulous observation, record keeping, and attention to detail. The brothers excelled at efficiently and effectively identifying, isolating, and then pragmatically solving problems. Their success depended upon quiet self-confidence and their unwavering resolve.

Readers may draw innumerable lessons from these examples. Although the quest for models and case studies-much like the pursuit of innovation - is endless, commencing the journey is the first critical step. $\mathbf{C M}$

\section{ABOUT THE AUTHORS}

STEVEN L. SCHOONER, CPCM, NCMA

FELLOW, is the Nash \& Cibinic Professor of Government Procurement Law at The George Washington University Law School. Before joining the faculty, he was the associate administrator for Procurement Law and Legislation at the Office of Federal Procurement Policy. He received NCMA's Charles A. Dana Distinguished Service Award in 2012. Prof. Schooner gratefully acknowledges Seymour Herman for his continued support of government procurement law research at the George Washington University Law School.

NATHANIEL E. CASTELLANO is a graduate of the George Washington University Law School, where he was recognized as the Murray Schooner Scholar for excellence in the study of government procurement law. At the time of publication, he was an associate in the Government Contracts and National Security practice of Arnold \& Porter LLP. He will begin a term as a law clerk for the Honorable Jimmie V. Reyna on the U.S. Court of Appeals for the Federal Circuit beginning in mid-April 2016.

\section{Send comments about this article to} cm@ncmahq.org.

\section{ENDNOTES}

1. Frank Kendall, "Performance of the Defense Acquisition System: 2015 Annual Report" (September 16, 2015), available at www.acq. osd.mil/fo/docs/Performance-of-DefenseAcquisition-System-2015.pdf

See Kendall, ibid.; and Steven L. Schooner and Nathaniel E. Castellano, "Review Essay: Reading The Dream Machine: The Untold Story of the Notorious V-22 Osprey, by Richard Whittle, in Light of the Defense Acquisition Performance Study," Public Contract Law Journal (2014). (But see Steven L. Schooner and Nathaniel E. Castellano, "Dawn Of the Intercontinental Sniper: The Drone's Cascading Contribution to the Modern Battlefield's Complexity, Review of Predator: The Secret Origins of the Drone Revo lution, by Richard Whittle," Journal of National Security Law \& Policy (pending, 2016).)

3. See, e.g., Secretary of Defense Chuck Hagel, "Defense Innovation Initiative" (November 15, 2014), available at www.defense.gov/Portals/ 1/Documents/pubs/OSD013411-14.pdf; and Defense Innovation Marketplace, www. defenseinnovationmarketplace.mil/. See also Sandra I. Erwin, "Defense Innovation Initiative Burdened by High Expectations," National Defense (November 30, 2014), available at www.nationaldefensemagazine.org/blog/ Lists/Posts/Post.aspx?ID=2031.

4. Frank Kendall, Testimony Before the House Committee on Armed Services (January 28, 2015): 3, available at www. defenseinnovationmarketplace.milresources/ USD(ATL)WrittenStmtHASC20150128Final.pdf. See also Dan Steinbock, "The Challenges for America's Defense Innovation," The Informa- 
tion Technology \& Innovation Foundation (November 2014): 17, available at http:// www2.itif.org/2014-defense-rd.pdf ("[T]he Pentagon's investment in research, development, testing, and evaluation... has fallen 28 percent since its peak in 2009, adjusting for inflation.... According to the Pentagon, R\&D spending will continue to bear the brunt of defense budget cuts.")

5. David McCullough, The Wright Brothers (New York: Simon \& Schuster, 2015)

6. To be clear, the brothers' lack of education in no way suggested a lack of intellectual capacity or curiosity. Indeed, McCullough describes a horrific ice hockey accident (or potentially, incident) that derailed Wilbur's plans to pursue studies at Yale. More important, McCullough repeatedly emphasizes that the Wright family home valued books, and the brothers read widely, voraciously, and critically.

7. See Steven L. Schooner and Nathaniel E. Castellano, "Eyes on the Prize, Head in the Sand: Filling the Due Process Vacuum in Federally Administered Contests," Federal Circuit Bar Journal (2015); Leonard Rawicz, "Federal Inducement Prizes," Briefing Papers (August 2015); Richard Dunn and Rebekah Higgitt, Ships, Clocks, \& Stars: The Quest for Longitude (2014); Dava Sobel, Longitude: The True Story Of A Lone Genius Who Solved The Greatest Scientific Problem Of His Time (1995); and Jonathan R. Siegel, "Law and Longitude," Tulane Law Review (2009).

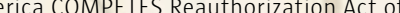
2010, Pub. L. 111-358 \$105(a), 124 Stat. 3982, 3989 (2011) (codified at 15 U.S.C. 3719(b) (2012)); and the Office of Science \& Technology Policy, "Implementation of Federal Prize Authority: Progress Report” (2012), available at www.nasa.gov/sites/default/files/files/ competes_report_on_prizes_final.pdf. See also the U.S. federal government's hub for federal incentive prize and challenge competitions (www.challenge.gov)

9. See Schooner and Castellano, note 7, at 404 .

10. See Kenneth Change, "First Private Craft Docks With Space Station," New York Times (May 25 2012) ("Space Exploration Technologies Corporation of Hawthorne, Calif., or SpaceX, made history as the first private company to send a craft, the Dragon, to the station."), available at www. nytimes.com/2012/05/26/science/space/ space-x-capsule-docks-at-space-station.html.

11. See, e.g., "Lockheed Martin finalizes $\$ 9 \mathrm{~B}$ purchase of Connecticut military helicopter maker Sikorsky," Associated Press (November 6 2015), available at www.newsjs.com/url. php?p=http://www.usnews.com/news/ business/articles/2015/11/06/lockheedfinalizes-gb-purchase-of-helicoptermaker-sikorsky.

12. The Wright Brothers, at 107-108. Later, "Smithsonian officials misleadingly identified the Aerodrome A...as the world's first airplane 'capable of sustained free flight'... [which] partly...prompted Orville Wright in 1928 to lend the 1903 Flyer to the Science Museum in London as a gesture of protest regarding the Smithsonian's seeming unwillingness to give him and his brother, Wilbur, full credit for having invented the airplane." (Langley Aerodrome A, Smithsonian National Air and Space Museum, http://airandspace.si.edu/ collections/artifact.cfm?object=nasm_ A19180001000.)

13. We remain enchanted by Richard Whittle's eloquent riff on the Predator's evolution: "This is the drone revolution's book of genesis, and like another creation story, it opens near the confluence of the rivers Tigris and Euphrates. It begins with a boy in Baghdad." (Richard Whittle, Predator: The Secret Origins of the Drone Revolution (2014): 6.)

14. We do not suggest that the joint strike fighter is an isolated example. See, e.g., Christian Dav enport, "Why John McCain called this \$13 billion aircraft carrier a 'spectacular' debacle," Washington Post (October 1, 2015): "Like many other programs, the...carriers suffered from unrealistic cost estimates and overly optimistic timelines.... Pentagon officials pushed the program forward even though key technologies hadn't been fully tested, developed, or designed.... 'The Navy can be faulted for excessive optimism and deficient realism...,' [McCain] said. [USD(AT\&L)] authorized the Navy to begin construction 'when only 27 percent of the ship was designed and just five of its 13 new systems were mature...."

15. See, e.g., FAR Part 34, particularly Sections 24.005-4, 5, and 6 ("Contracts for full production of successfully tested major systems selected from the full-scale development phase may be awarded"); see also DOD Instruction 5000.02 (January 7, 2015) ("Competitive proto types are part of [Milestone A] unless specifically waived...."), available at www.dtic.mil/ whs/directives/corres/pdf/500002p.pdf.

16. In so doing, the U.S. Air Force will guarantee decades of R\&D and production funding to a single contractor based on a paper proposal. Of course, competitive prototyping is not a panacea, as the ongoing joint strike fighter saga appears to demonstrate.

17. At a minimum, life cycle cost adds 1 ) transaction costs, 2) operating costs, 3) maintenance costs, and 4) disposition costs (which can be a positive or negative number), to 5) purchase price, to provide a more realistic assessment of the expenditure necessary to exploit or deploy a solution.

18. The Gramm-Rudman-Hollings Balanced Budget and Emergency Deficit Control Act of 1985 made annual deficit spending the metric by which federal fiscal responsibility is evaluated, creating massive incentives for bureaucrats and legislators alike to prioritize short-term savings over all other means of financial prudence, and making annual deficits a constant trigger for public hysteria, regardless of the underlying reason for those deficits. See Gramm-Rudman-Hollings Balanced Budget and Emergency Deficit Control Act of 1985, Pub. L. No. 99-177, 99 Stat. 1037, 1039 (1985); and Christopher D. Dodge, "Doomed to Repeat: Why Sequestration and the Budget Control Act of 2011 Are Unlikely to Solve Our Solvency Woes," New York University Journal of Legislation \& Public Policy (2012)
19. The tortured history of the $\mathrm{V}-22$ owes much to a small number of high-profile accidents and fatalities during the program's development. (See Schooner and Castellano, note 2, at 414-416.)

20. McCullough, see note 5 , at 181-203. Selfridge graduated from the U.S. Military Academy with Douglas MacArthur in 1903.

21. Ibid., at 67-68

22. Kendall, see note 1

23. Once, as 4,000 disappointed spectators dis persed after conditions forced the brothers to cancel the flight test, a senator remarked: "I’m damned if I don't admire their independence. We don't mean anything to them, and there are a whole lot of reasons why we shouldn't." (McCullough, see note 5, at 234-235.)

24. Dan Steinbock, "The Challenges for America's Defense Innovation," The Information Technology \& Innovation Foundation (November 2014): 20-21, available at http://www2.itif.org/2014defense-rd.pdf.

25. Even after its own leviathan project-the Langley "Great Aerodrome"-sank in shambles, when Senator Henry Cabot Lodge notified the War Department of the Wright brothers' success at Kitty Hawk, the War Department failed to take the Wright brothers seriously. Before taking their wares to Europe, the Wright brothers wrote to Secretary of War William Hoard Taft that: "During 1904 they had made 105 flights, flying in straight lines, circles, over S-shaped courses, in calms and great winds, and brought flying to the point where it could be of great practical use in various ways, 'one of which is that of scouting and carrying messages in time of war."' (McCullough, see note 5, at 123.)

26. Ibid., at 123

27. See, generally, Arms Export Control Act (AECA), 22 U.S.C. 2751, et seq.; International Trafficking in Arms Regulations (ITAR), 22 C.F.R. 120-130; Directorate of Defense Trade Controls (DDTC), available at www.pmddtc.state.gov/index. html; and Joseph D. West, Judith A. Lee, and Jason A. Monahan; "U.S. Export Control Compliance Requirements for Government Contractors," Briefing Papers Collection 05-12 (November 2005).

28. For an extensive analysis of the contract from a different perspective (in the context of performance-based service contracting, see Vernon I. Edwards, "The True Story of the Wright Brothers' Contract (It's not what you think.)," Where in Federal Contracting (July 2002), available at www.wifcon.com/anal/ analwright.htm 